\title{
Controls on zooplankton methane production in the central Baltic Sea
}

\author{
Beate Stawiarski ${ }^{1}$, Stefan Otto ${ }^{1}$, Volker Thiel ${ }^{2}$, Ulf Gräwe ${ }^{1}$, Natalie Loick-Wilde ${ }^{1}$, Anna K. Wittenborn ${ }^{1,2}$, \\ Stefan Schloemer ${ }^{3}$, Janine Wäge ${ }^{1}$, Gregor Rehder ${ }^{1}$, Matthias Labrenz ${ }^{1}$, Norbert Wasmund ${ }^{1}$, and Oliver Schmale ${ }^{1}$ \\ ${ }^{1}$ Leibniz Institute for Baltic Sea Research Warnemünde, Seestrasse 15, 18119 Rostock, Germany \\ ${ }^{2}$ Geoscience Center, Georg-August University of Göttingen, Goldschmidtstr. 3, 37077 Göttingen, Germany \\ ${ }^{3}$ Federal Institute for Geosciences and Natural Resources, Stilleweg 2, 30655 Hannover, Germany
}

Correspondence: Oliver Schmale (oliver.schmale@io-warnemuende.de)

Received: 18 July 2018 - Discussion started: 9 August 2018

Revised: 23 October 2018 - Accepted: 27 November 2018 - Published: 7 January 2019

\begin{abstract}
Several methanogenic pathways in oxic surface waters were recently discovered, but their relevance in the natural environment is still unknown. Our study examines distinct methane $\left(\mathrm{CH}_{4}\right)$ enrichments that repeatedly occur below the thermocline during the summer months in the central Baltic Sea. In agreement with previous studies in this region, we discovered differences in the methane distributions between the western and eastern Gotland Basin, pointing to in situ methane production below the thermocline in the latter (concentration of $\mathrm{CH}_{4} 14.1 \pm 6.1 \mathrm{nM}, \delta^{13} \mathrm{C} \mathrm{CH}_{4}-62.9 \%$ ). Through the use of a high-resolution hydrographic model of the Baltic Sea, we showed that methane below the thermocline can be transported by upwelling events towards the sea surface, thus contributing to the methane flux at the sea-air interface. To quantify zooplankton-associated methane production rates, we developed a sea-going methane stripping-oxidation line to determine methane release rates from copepods grazing on ${ }^{14} \mathrm{C}$-labelled phytoplankton. We found that (1) methane production increased with the number of copepods, (2) higher methane production rates were measured in incubations with Temora longicornis (125 \pm $49 \mathrm{fmol} \mathrm{methane} \mathrm{copepod}{ }^{-1} \mathrm{~d}^{-1}$ ) than in incubations with Acartia spp. $\left(84 \pm 19 \mathrm{fmol} \mathrm{CH}_{4}\right.$ copepod $\left.{ }^{-1} \mathrm{~d}^{-1}\right)$ dominated zooplankton communities, and (3) methane was only produced on a Rhodomonas sp. diet, and not on a cyanobacteria diet. Furthermore, copepod-specific methane production rates increased with incubation time. The latter finding suggests that methanogenic substrates for water-dwelling microbes are released by cell disruption during feeding, defecation, or diffusion from fecal pellets. In the field, par-
\end{abstract}

ticularly high methane concentrations coincided with stations showing a high abundance of DMSP/DMSO-rich Dinophyceae. Lipid biomarkers extracted from phytoplanktonand copepod-rich samples revealed that Dinophyceae are a major food source of the T. longicornis dominated zooplankton community, supporting the proposed link between copepod grazing, DMSP/DMSO release, and the build-up of subthermocline methane enrichments in the central Baltic Sea.

\section{Introduction}

Climate change, caused by increased greenhouse gas concentrations in the atmosphere, has an indisputable influence on societal and economical evolution on local, regional and global scales. In order to better predict future climate development, a more precise quantitative and mechanistic understanding of individual sources and sinks of relevant greenhouse gases, such as methane, is crucial. Methane as an atmospheric component has a relevant impact on the earth's climate (Etminan et al., 2016; IPCC, 2013). In general, biogenic sources of methane are associated with microorganisms (Archaea) in anoxic habitats, for example, in the ocean and lake sediments, wetlands, landfills, rice fields or the gastrointestinal tracts of termites and ruminants (IPCC, 2013). However, recent studies demonstrated that methanogenesis also occurs in oxic environments. These unconventional methanogenic pathways are mediated by aerobic prokaryotes (Yao et al., 2016) as well as eukaryotes, including plants (Keppler et al., 2006; Lenhart et al., 2016), animals 
(Tuboly et al., 2013), lichens (Lenhart et al., 2015), and fungi (Lenhart et al., 2012).

Methane concentrations in the oxygenated surface ocean and lake waters show strong regional and seasonal fluctuations (e.g. Jakobs et al., 2014; Donis et al., 2017). Large areas are supersaturated with methane and act as a net source to the atmosphere (e.g. Bange et al., 1994; Lamontagne et al., 1973; Tang et al., 2014). It is assumed that climate-driven modifications in aquatic systems such as increasing water temperatures, enhanced stratification, and nutrient limitation could further reinforce aquatic methane production (Karl et al., 2008). Such modifications are particularly important for shallow oxic methane production that largely bypasses microbial methane consumption as it places the methane source close to the water surface, intensifying fluxes to the atmosphere. However, the origin of methane in the oxic upper water column is still unclear and hence also referred to as the "methane paradox" (Scranton and Brewer, 1977).

Recently, a growing number of studies have identified several pathways that could explain methane enrichments in shallow oxic waters. The postulated $\mathrm{CH}_{4}$ production pathways include (i) direct $\mathrm{CH}_{4}$ production by algae from methyl sulfides such as methionine (Lenhart et al., 2016); (ii) bacterial break-down of methylphosphonate (MPn) under phosphate-stressed conditions (Repeta et al., 2016; Karl et al., 2008; Wang et al., 2017; Teikari et al., 2018); (iii) transfer of diazotroph-derived hydrogen among methanogens attached to algae (Grossart et al., 2011); (iv) $\mathrm{CH}_{4}$ production through microbial degradation of dimethylsulfide (DMS), dimethylsulfoniopropionate (DMSP) and dimethylsulfoxide (DMSO; Damm et al., 2010; Zindler et al., 2013); (v) photochemical production of methane from coloured dissolved organic matter (chromophoric dissolved organic matter, Zhang and Xie, 2015); and (vi) the microbial formation of methane in anoxic microniches within decaying organic aggregates or zooplankton fecal pellets (Holmes et al., 2000; Karl and Tilbrook, 1994; Oremland, 1979). The latter hypothesis is supported by oxygen microsensor studies that showed that anoxic conditions can exist in carbon- and nutrient-rich aggregates (Ploug, 2001; Ploug et al., 1997, 2008; Ploug and Jørgensen, 1999). Furthermore, molecular biological studies identified methanogenic archaea within fecal pellets produced by Temora longicornis and Acartia clausi (Ditchfield et al., 2012). These results are in agreement with the studies conducted by de Angelis and Lee (1994), who observed methane production during experimental zooplankton grazing on unialgal cultures. The authors used selected growth stages (adult and C5 stages) from pure cultures of T. longicornis, Acartia tonsa, and Calanus pacificus, which had been isolated from the coastal waters from the North Atlantic. In these laboratory experiments, methane production was only detected in incubations containing T. longicornis.

The Baltic Sea is characterized by pronounced lateral gradients including e.g. temperature, salinity, oxygen and methane concentrations, which altogether strongly influence the biology of the ecosystem (Feistel et al., 2008, and references therein). It consists of several sub-basins, of which the eastern Gotland Basin is the largest. The eastern Gotland Basin has a maximum depth of $248 \mathrm{~m}$ and establishes a seasonal thermocline at $10-30 \mathrm{~m}$ water depth in the summer months, and a permanent halocline at 70-90 m (Omstedt et al., 2004). In general, bottom waters in this basin are anoxic, unless episodic inflow events of more saline and oxygen-rich North Sea water into the deep basins lead to temporary oxic conditions (Franck et al., 1987; Mohrholz et al., 2015).

Methane concentrations in the Baltic Sea tend to increase with depth due to its release from the anoxic sediments (Schmale et al., 2010). However, recent studies revealed a recurring methane accumulation in oxic waters right below the thermocline during the summer months (Jakobs et al., 2014; Schmale et al., 2018). Stable carbon isotopes indicated an in situ biogenic methane origin, whereas clonal sequences pointed towards methanogenic Archaea as potential producers (Schmale et al., 2018). It was further shown that zooplankton-associated methane production contributed to the subthermocline methane enrichment (Schmale et al., 2018). The authors found that methane increased with increasing amounts of zooplankton and they suggested that changes in the copepod community and food web structure may influence the spatial heterogeneity of methane accumulation in the upper part of the water column. However, zooplankton-associated methane production rates alone were not sufficient to fully explain the observed methane enrichment. They concluded that this was most likely a consequence of using incubations with very dense and probably food-limited zooplankton communities (1000 times the natural density), leading to results that are difficult to transfer into the natural environment (Schmale et al., 2018). To overcome these experimental deficits, we developed a methane stripping-oxidation line to study zooplanktonassociated methane production rates in the field. Our shipbased incubation experiments were performed with different zooplankton communities obtained from either the surface or from below the thermocline. We used almost natural copepod densities (1.5-8.5 times the natural density), and different diets of ${ }^{14} \mathrm{C}$-labelled phytoplankton. In conjunction with field investigations of methane concentrations and plankton distributions, the present study gives important insights into the controls of zooplankton-associated methane production in the central Baltic Sea.

\section{Methods}

\subsection{Hydrographical and chemical characteristics of the water column}

During cruise AL483 on R/V Alkor in August 2016 in the central Baltic Sea, seven stations in the western (TF0283, TF0284) and eastern (from south to north: TF0250, TF0260, 


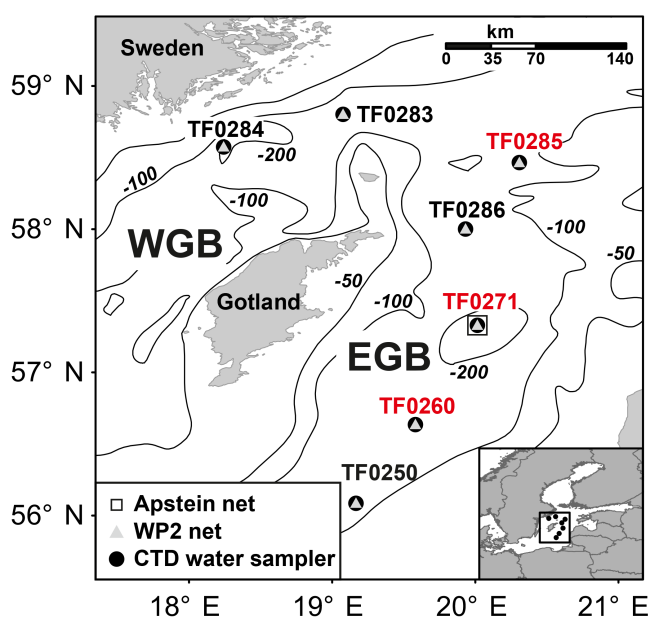

Figure 1. Map of sampling stations in the western Gotland Basin (WGB) and the eastern Gotland Basin (EGB). Symbols describe the sampling gear. Stations with a distinct subthermocline methane enrichment are marked in red.

TF0271, TF0286, TF0285) Gotland Basin (Fig. 1) were investigated. At each station, the hydrographical variables, including temperature, salinity and oxygen concentrations, of the water column were examined along vertical profiles using a SBE 911 plus CTD system (Seabird Electronics, USA; see Sect. S1 in the Supplement). In addition, the vertical methane distribution pattern and the stable carbon isotope ratio of methane $\left(\delta^{13} \mathrm{C} \mathrm{CH}_{4}\right)$ were measured to differentiate between regions affected and regions unaffected by subthermocline methane production. For these studies, subsamples were taken from the rosette water sampler and analysed in the home laboratory using a purge and trap system for methane concentration measurements and a continuous-flow isotope ratio mass spectrometer (IRMS) for stable carbon isotope analyses (see Sect. S1). In order to investigate whether station TF0284 was affected by coastal upwelling during the time of sampling, we analysed the output of a numerical ocean model, covering the North Sea/Baltic Sea. This hydrodynamical model computed a reconstruction of the state of the Baltic Sea with a spatial resolution of 1 nautical mile and 50 vertical levels. Further details of the model are given in Gräwe et al. (2015).

Surface water methane saturation is calculated following Eq. (1), where SV is the saturation value, $C_{w}$ the measured concentration of methane in seawater and $C_{\text {equi }}$ the concentration in equilibrium with the atmosphere using the solubility coefficient given by Wiesenburg et al. (1979).

$\mathrm{SV}[\%]=\frac{C_{w}}{C_{\text {equi }}} \cdot 100$

\subsection{Plankton community and lipid biomarker analyses}

Phytoplankton samples for water column community analysis were taken from the $10 \mathrm{~L}$ free-flow bottles at stations
TF0271, TF0284 and TF0286 (Fig. 1). Equal amounts of water from the mixed layer (depths: $0-1,2.5,5,7.5$ and $10 \mathrm{~m}$ ) were pooled in accordance with the guidelines of the Helsinki Commission (HELCOM, 2017). At stations characterized by a distinct subthermocline methane enrichment (TF0271, TF0260, TF0285 and TF0286), additional samples were taken from the subthermocline chlorophyll $a$ maximum at about $20 \mathrm{~m}$ water depth. At station TF0271, three samples were taken on 12 and 18 August to investigate the temporal variability in the community composition at this location. All phytoplankton samples were transferred into $250 \mathrm{~mL}$ brown glass bottles and preserved with $1 \mathrm{~mL}$ of acetic Lugol solution (2\% final concentration). For later community analyses, $25 \mathrm{~mL}$ sub-samples were concentrated in settling chambers (Utermöhl, 1958). They were counted using an inverted microscope and the counts were converted into carbon biomass using the cell volumes (Olenina et al., 2006; HELCOM, 2017).

Zooplankton samples for water column community analyses were collected with a WP2 net (towed at $0.5 \mathrm{~m} \mathrm{~s}^{-1}$, mouth opening, $25 \mathrm{~m}^{2}$, mesh size $100 \mu \mathrm{m}$, according to HELCOM, 2017) independent of daytime. Vertically integrated hauls from two depth intervals were taken to obtain zooplankton samples: (i) thermocline to surface (e.g. 20-0 m, depending on the physical structure of the water column), and (ii) halocline to thermocline (e.g. 60-20 m). The concentrated samples $(500 \mathrm{~mL})$ were preserved in borax-buffered formalin (4\% final concentration). For later copepod-specific community analyses, sub-samples were counted using a compound microscope until at least 500 individual copepods were taxonomically classified. Nauplii were pooled together for all copepod species, while $\mathrm{C} 1-\mathrm{C} 5$ copepodite stages and adults were pooled for individual species. Finally, to exclude potential daytime effects through vertical migration of the zooplankton communities above the halocline, counts from both integrated hauls were averaged according to the filtered volume. Similar to the phytoplankton sampling strategy, three samples at TF0271 were taken in a period of 10 days to investigate the temporal variability in the community composition at this station.

Lipid biomarkers were analysed to obtain information on the trophic relationships of copepods in the field at station TF0271 that showed a distinct methane enrichment below the thermocline. For this purpose, their putative food source, phytoplankton in the mixed layer, was sampled with an Apstein net. The phytoplankton were separated from cosampled zooplankton using a simple self-built trap consisting of a $1.5 \mathrm{~L}$ transparent plastic bottle with a closable outlet at the bottom. The zooplankton were attracted towards the trap using a light source attached close to the outlet, and drained off. Then the phytoplankton, which remained in the bottle, were sampled. The target copepod T. longicornis has been known to migrate diurnally from the light-penetrated surface layer towards greater depths to escape predation (Hansen et al., 2006; Schmale et al., 2018). For lipid biomarker studies, 
a concentrated sample of zooplankton rich in T. longicornis was retrieved, avoiding major co-sampling of phytoplankton. This sampling was performed at station TF0271 by hauling a WP-2 net (see above) in the subthermocline layer $(25-60 \mathrm{~m})$ during the daytime. For comparison, a zooplankton sample was taken at station TF0250 without a distinct methane enrichment below the thermocline. Here, the community composition was low in T. longicornis and instead was dominated by Acartia spp. and Pseudocalanus spp. All samples were concentrated by sieving $(20 \mu \mathrm{m})$ and kept frozen until further workup in the home laboratory. The samples were lyophilized and extracted $\left(3 \times\right.$, ultrasound, $\left.15 \mathrm{~min}, 20^{\circ} \mathrm{C}\right)$ with dichloromethane (DCM) / methanol $(\mathrm{MeOH})(2: 1, v$ : $v), \mathrm{DCM} / \mathrm{MeOH}(3: 1, v: v)$ and DCM / $n$-hexane $(2: 1$, $v: v$ ). From the resulting total organic extract, neutral lipids (NL, largely containing storage lipids such as triglycerides, wax esters, and sterols) were separated using silica gel column chromatography by elution with DCM / acetone (9: $1, v: v)$. After drying, fatty acids (FA) in the NL fraction were transesterified by reaction with trimethylchlorosilane (TMCS) / $\mathrm{MeOH}\left(1: 9, v: v ; 90 \mathrm{~min}, 80^{\circ} \mathrm{C}\right)$. After partitioning into $n$-hexane $(3 \times, 1 \mathrm{~mL})$ and drying, alcohols contained in the NL were converted to their trimethylsilyl (TMS-) derivatives by reacting with $200 \mu \mathrm{l}$ of a $n$ hexane/BSTFA/pyridine mixture $\left(5: 3: 2, v: v: v ; 40{ }^{\circ} \mathrm{C}\right.$, $60 \mathrm{~min})$. The derivatized NL fractions were analysed by coupled gas chromatography-mass spectrometry (GC-MS), as described elsewhere (Thiel and Hoppert 2018).

\subsection{Sampling for ship-based laboratory experiments}

Three ship-based grazing experiments were conducted at station TF0271, where a persistent and distinct methane enrichment below the thermocline was detected during the cruise. These experiments were designed to examine how (i) the abundance of copepods and (ii) their food source impact zooplankton-associated methane production, and how (iii) the methane production rates vary between different copepod communities. To measure copepod species-specific methane production rates, zooplankton communities were sampled from the surface (e.g. $20-0 \mathrm{~m}$ ) and from the subthermocline waters (e.g. 60-20 m). In the central Baltic Sea, these layers are commonly dominated by Acartia spp. and T. longicornis, respectively (Hansen et al., 2006), and will be referred to as the surface and subthermocline communities. For the sampling hauls the cod end of the WP2 net was sealed from outside and towed $0.1 \mathrm{~m} \mathrm{~s}^{-1}$ to reduce damage to the zooplankton, and the content was transferred immediately into a $25 \mathrm{~L}$ bucket filled with seawater from the depth where the zooplankton was sampled (i.e. surface or subthermocline water). The zooplankton mainly comprised copepods and was left in the cold room at $10^{\circ} \mathrm{C}$ for an hour to allow damaged individuals to settle to the bottom of the bucket. A subsample of living copepods was removed gently with a $500 \mathrm{~mL}$ beaker from the upper layer of the bucket to avoid injured animals, and checked for species composition under the dissecting microscope before subsamples were used for the grazing experiments. The sampling took place at 14:00 UTC, before vertical migration of one of the target copepods, T. longicornis, started (Hansen et al., 2006). This time was chosen because it was more likely that $T$. longicornis in the deeper water column would be starved and, thus, would start grazing within the experiments.

Two phytoplankton compositions were used to test for the influence of the diet on zooplankton-associated methane production: (i) a Rhodomonas sp. (Cryptophyceae) laboratory culture, and (ii) a Nodularia spumigena (Cyanophyceae) dominated culture from the surface mixed layer in the field, which is typically found in these waters of the central Baltic Sea in summer (Wasmund, 1997). The laboratory culture of Rhodomonas sp. was grown in f/2 medium (Guillard, 1962), prepared in autoclaved bottles from $0.2 \mu \mathrm{m}$ filtered seawater from $10 \mathrm{~m}$ depth. A new sub-culture was established every 3-5 days and the inoculum was chosen to be sufficient to keep the culture in exponential growth (cf. Knuckey et al., 2005). The second phytoplankton culture was established from the top chlorophyll $a$ fluorescence maximum $(0-10 \mathrm{~m})$ sampled with an Apstein net (55 $\mu \mathrm{m}$ mesh size, Hydro-Bios). The culture was re-suspended in $500 \mathrm{~mL}$ of seawater and left for an hour to allow the $N$. spumigena cells to float on top. The cells were carefully collected with a pipette and transferred into an autoclaved $1 \mathrm{~L}$ glass bottle, which was filled up with surface seawater. Then, $36.2 \mu \mathrm{M}$ of $\mathrm{NaH}_{2} \mathrm{PO}_{4}$ as for the $\mathrm{f} / 2$ medium was added. Both the Rhodomonas sp. and the $N$. spumigena culture bottles were incubated in $90 \mathrm{~L}$ tubs, which were placed in a shaded location on deck and continuously flushed with sea surface water at a temperature of $\sim 18.5^{\circ} \mathrm{C}$. A third phytoplankton culture was collected from a subthermocline chlorophyll $a$ peak closely below the thermocline ( $20 \mathrm{~m}$ depth), where mixotrophic Dinophyceae were expected to be dominant (Carpenter et al., 1995; Hällfors et al., 2011). For this, up to $150 \mathrm{~L}$ of seawater was obtained from a CTD rosette and concentrated on a $20 \mu \mathrm{m}$ mesh. However, this culture did not grow sufficiently under similar temperature and light conditions as in situ, and could not be used within the grazing experiments.

\subsection{Phytoplankton ${ }^{14} \mathrm{C}$-labelling}

Once a phytoplankton culture was selected for grazing experiments, three aliquots were split between three autoclaved $1 \mathrm{~L}$ incubation bottles $\left(\mathrm{DURAN}^{\circledR}\right.$, borosilicate glass 3.3 , clear, GL45) and filled up with the corresponding medium. One of these bottles was spiked with $18.5 \mathrm{MBq}$ of ${ }^{14} \mathrm{C}$ labelled sodium bicarbonate $\left(\mathrm{NaHCO}_{3}, 2.18 \mathrm{GBq} \mathrm{mmol}^{-1}\right.$, Moravek Biochemicals, USA) for ${ }^{14} \mathrm{CH}_{4}$ production measurements (Sect. 2.5.1 Methane production and consumption rates). The other two bottles received equal amounts of unlabelled $\mathrm{NaHCO}_{3}$ for measuring the particulate organic carbon concentration (Sect. 2.5.2 Analysis of particulate organic 
Table 1. Experimental conditions for the zooplankton grazing experiments (exp.). $\mathrm{SA}_{\text {phy }}$ is the specific activity of the phytoplankton fed to the copepods. POC stands for particulate organic carbon. No. of copepods is the average amount of copepods used in the incubation experiments.

\begin{tabular}{|c|c|c|c|c|c|c|c|}
\hline Exp. & Food & $\begin{array}{c}\text { SA }_{\text {phy }} \\
\left(\mathrm{MBqmmol}^{-1}\right)\end{array}$ & $\begin{array}{l}\text { POC conc. } \\
\text { at start } \\
\left(\mathrm{mg} \mathrm{CL}^{-1}\right)\end{array}$ & $\begin{array}{l}\text { POC conc. } \\
\text { at end } \\
\left(\mathrm{mg} \mathrm{CL}^{-1}\right)\end{array}$ & $\begin{array}{l}\text { Zooplankton } \\
\text { community }\end{array}$ & $\begin{array}{r}\text { No. of } \\
\text { copepods }\end{array}$ & $\begin{array}{l}\text { Duration of } \\
\text { the exp. }(d)\end{array}$ \\
\hline 1 & Rhodomonas sp. & 695.23 & $1.34 \pm 0.04$ & $1.24 \pm 0.08$ & subthermocline & $\begin{array}{r}25 \pm 3 \\
56 \pm 2 \\
73 \pm 2 \\
25 \pm 8 \\
50 \pm 12 \\
76 \pm 18\end{array}$ & 1 \\
\hline 2 & Rhodomonas sp. & 613.46 & $1.61 \pm 0.61$ & $1.73 \pm 0.45$ & subthermocline & $64 \pm 3$ & $1-3$ \\
\hline 3 & $\begin{array}{l}\text { Nodularia } \\
\text { spumigena }\end{array}$ & 299.33 & $3.17 \pm 0.26$ & $3.09 \pm 1.18$ & subthermocline & $66 \pm 7$ & $1-3$ \\
\hline
\end{tabular}

carbon) and microbial methane consumption (Sect. 2.5.1 Methane production and consumption rates). All bottles were incubated for 3-5 days to allow cells to grow and to take up the ${ }^{14} \mathrm{C}$ label (Welschmeyer and Lorenzen, 1984). The specific activity of the labelled phytoplankton $\left(\mathrm{SA}_{\mathrm{phy}}\right)$ was measured daily by filtering $1-5 \mathrm{~mL}$ of the culture through a $0.45 \mu \mathrm{m}$ cellulose nitrate filter (Millipore) and rinsing it thoroughly with Milli-Q water. The filter was then dissolved in Filter Count scintillation cocktail (Perkin Elmer) by vortexing and the amount of ${ }^{14} \mathrm{C}$ label that was incorporated into particles was measured on a liquid scintillation counter (Perkin Elmer, Tri-Carb 2800TR). Blanks for the specific activity of the cultures were collected and analysed immediately after the label had been added to the incubation bottle.

$\mathrm{SA}_{\text {phy }}$ was calculated using Eq. (2) and used for calculating methane production rates (de Angelis and Lee, 1994), where $\mathrm{SA}_{\mathrm{phy}}$ is the specific activity of the phytoplankton, Disintegrations $_{\text {filter }}$ are the disintegrations $\mathrm{mL}^{-1}$ on the fil-

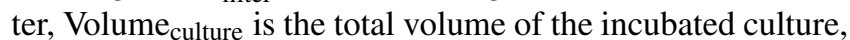
$6 \times 10^{7} \mathrm{dpm} \mathrm{MBq}^{-1}$ is the constant for converting dpm into units of $\mathrm{MBq}$, activity added $_{\text {in }}$ is the total activity of the tracer, which was added to the incubation, and $\mathrm{SA}_{\text {tracer }}$ is the specific activity of the tracer.

$$
\begin{aligned}
& \mathrm{SA}_{\text {phy }}\left[\frac{\mathrm{MBq}}{\mathrm{mmol}}\right]= \\
& \frac{\text { disintegrations }_{\text {filter }}\left[\frac{\mathrm{dpm}}{\mathrm{mL}}\right] \times \text { Volume }_{\text {culture }}[\mathrm{mL}]}{6 \times 10^{7}\left[\frac{\mathrm{dpm}}{\mathrm{MBq}}\right]} \\
& \times \frac{1}{\text { activity }_{\text {added }}[\mathrm{MBq}]} \times \mathrm{SA}_{\text {tracer }}\left[\frac{\mathrm{MBq}}{\mathrm{mmol}}\right]
\end{aligned}
$$

\subsection{Zooplankton grazing experiments}

Three experiments with zooplankton grazing on phytoplankton (Table 1) were conducted. In experiment 1 we tested whether there was (i) a linear relationship between methane produced and the number of copepods incubated, and (ii) a difference in methane production between the surface and subthermocline zooplankton communities. In experiment 2 only the subthermocline zooplankton community was used and the incubation time was varied from 1 to 3 days to test whether the increase in methane was stable over time and the production rate per copepod stayed constant. In experiments 1 and 2 a laboratory strain of Rhodomonas sp. (Cryptophyceae), a standard food for copepod culturing (Dutz et al., 2008), was fed to the zooplankton communities. Rhodomonas sp. may be considered a model representative of the Cryptophyceae, which account for $5.5 \%$ of the total phytoplankton biomass in the Baltic Sea in summer 2016 (IOW monitoring database: https://www.io-warnemuende. de/datenportal.html, last access: February 2018). In experiment 3 the subthermocline zooplankton community was fed the cyanobacterium $N$. spumigena and the incubation time was varied the same way as in experiment 2 . Here we selected $N$. spumigena as a food source, because this species was the dominant phytoplankton in the surface waters during our field campaign and accounted for $23 \%$ of the phytoplankton biomass. The different phytoplankton communities fed in these experiments allow one to assess the impact of the food source on zooplankton-associated methane production rates.

Each of the three grazing experiments consisted of three sets of incubations. The first set of incubations was conducted with zooplankton grazing on ${ }^{14} \mathrm{C}$-labelled phytoplankton for methane production measurements (Sect. 2.5.1 Methane production and consumption). The second set of incubations was conducted with zooplankton grazing on unlabelled phytoplankton to determine the food availability over the course of the grazing experiments (Sect. 2.5.2 Analysis of particulate organic carbon). Also, the third set of incubations was conducted with zooplankton grazing on unlabelled 
phytoplankton to measure the loss of methane by microbial oxidation under the experimental conditions (Sect. 2.5.1 Methane production and consumption).

In selective incubations the oxygen saturation was monitored over time using oxygen spots $(5 \mathrm{~mm}$, PreSens Precision Sensing) and an optode (Single Channel Oxygen Meter, Fibox 3 LCD, PreSens Precision Sensing). The average oxygen saturation was $75.2 \pm 2.9 \%$ throughout the experiments.

\subsubsection{Methane production and consumption rates}

For the methane production incubations, $250 \mathrm{~mL}$ gastight bottles (DURAN ${ }^{\circledR}$, borosilicate glass 3.3, clear, GL45) were used. The bottle lids were modified with one inlet and one outlet tube (Fig. 2), each sealed with autoclaved silicone stoppers. The inlet tube was long enough to reach into the lower third of the medium and had a glass frit attached at the end. The outlet tube was short enough to remain in the headspace of the bottle. Each bottle was filled with $50 \mathrm{~mL}$ of ${ }^{14} \mathrm{C}$-labelled phytoplankton and $3-15 \mathrm{~mL}$ of zooplankton stock culture and topped up to a total volume of $200 \mathrm{~mL}$ with $0.2 \mu \mathrm{m}$ filtered seawater (Millipore GVWP filter) from either 10 or $20 \mathrm{~m}$ depth, according to the depth from which the zooplankton community was obtained. All bottles were kept in the dark at in situ temperature for 1 to 3 days in temperaturecontrolled incubators. The methane, which was produced within the time of incubation, was finally measured with a methane stripping-oxidation line (modified following de Angelis and Lee, 1994; Fig. 2; details on the work principle in Sect. S2). In brief, the bottles were connected to the line, the water samples were purged with helium carrier gas and the methane (and other hydrocarbons) was concentrated on a cold trap. After heating the trap the methane was released and separated from other hydrocarbons by gas chromatography (GC) and transferred to a furnace, where it was converted to ${ }^{14} \mathrm{C}$-labelled carbon dioxide $\left(\mathrm{CO}_{2}\right)$. The ${ }^{14} \mathrm{CO}_{2}$ was trapped in scintillation vials and the activity was measured by liquid scintillation counting. Finally, the activities were used for calculating methane production rates with Eq. (3), where activity ${ }_{\text {zoo }+ \text { phy }}$ is the activity measured in incubations containing zooplankton and phytoplankton, and activity ${ }_{\text {phy }}$ is the activity measured in blank incubations.

$$
\begin{aligned}
& { }^{14} \mathrm{CH}_{4} \text { produced }[\mathrm{mmol}]= \\
& \frac{\text { activity }_{\text {zoo }+ \text { phy }}[\mathrm{MBq}]-\text { activity }_{\text {phy }}[\mathrm{MBq}]}{\mathrm{SA}_{\text {phy }}\left[\frac{\mathrm{MBq}}{\mathrm{mmol}}\right]}
\end{aligned}
$$

Blank incubations were conducted with phytoplankton and seawater only and the volume of zooplankton was replaced with the corresponding amount of GF/F (Whatman) filtered seawater in which the zooplankton was kept before incubations. The $\mathrm{CH}_{4}$ concentrations of all blank incubations were not different from the blank of the methane strippingoxidation line (Mann-Whitney $U$ test, $p=0.9, \mathrm{df}=1$ ).
Microbial methane oxidation rates were measured and the production rates corrected accordingly. For these measurements, ${ }^{14} \mathrm{C}$-labelled methane was injected into $600 \mathrm{~mL}$ incubation bottles, which were filled with the corresponding volumes of plankton and water as in the incubations for methane production measurements. The amount of produced ${ }^{14} \mathrm{CO}_{2}$ was measured according to the method of Jakobs et al. (2013). The rates were similar in all incubations and in the range of $0.13-0.44 \mathrm{pM} \mathrm{d}^{-1}$. Neither the presence of copepods nor the composition of their community or their food had a significant influence on the methane consumption rates. In incubations with Rhodomonas sp., methane oxidation rates were $0.13-0.39 \mathrm{pM} \mathrm{d}^{-1}$ and accounted for a loss of $0.2-2.3 \%$ of the produced methane. In incubations with cyanobacteria, the oxidation rates were slightly higher $(0.3-$ $0.44 \mathrm{pM} \mathrm{d}^{-1}$ ).

All sets of incubations included two to three replicates. To estimate the linear or exponential trends in methane concentration or production in relationship with the number of copepods or time, the Gauss-Newton method was used for minimizing the sum of squares between the fits and the measurements (Mystat 12, Systat software).

\subsubsection{Analysis of particulate organic carbon}

The particulate organic carbon (POC) content in the incubations was quantified at the beginning and end of our incubation experiments to determine the food availability over the course of the grazing experiments. For this, a larger volume of sample was required for later POC analysis using a Carlo Erba Elemental Analyser (Typ EA 1110; Carlo Erba; Nieuwenhuize et al., 1994), and 1 L bottles (DURAN ${ }^{\circledR}$, borosilicate glass 3.3, clear, GL45) were used for incubations. To achieve similar concentrations of zooplankton and phytoplankton $\left(\mathrm{mL}^{-1}\right)$ as in the first set of incubations, stock culture volumes were increased accordingly. For ambient POC analysis, one $50 \mathrm{~mL}$ sample was taken from each bottle at the beginning and at the end of the experiment on precombusted GF/F filters. The initial sample was removed from the experimental bottle before the copepods were added to it, and the final sample was taken after copepods had been removed with a $50 \mu \mathrm{m}$ sieve. All POC measurements (Table 1) at the beginning and at the end of the incubations exceeded the threshold for food limitation of $1-0.5 \mathrm{mg} \mathrm{C} \mathrm{L}^{-1}$ (Berggreen et al., 1988). As the food was diluted with $0.2 \mu \mathrm{m}$ filtered seawater, all POC at the beginning of the experiments can be assigned to the diet that was added. However, at the end of the grazing experiments, excreted fecal pellets of the zooplankton may have added up to the organic carbon pool. Further, it was difficult to separate the copepods from $N$. spumigena by the $50 \mu \mathrm{m}$ sieve, as $N$. spumigena typically exceeds $50 \mu \mathrm{m}$ in size. In consequence, no grazing rates based on the decrease in POC were calculated for the individual incubations. 


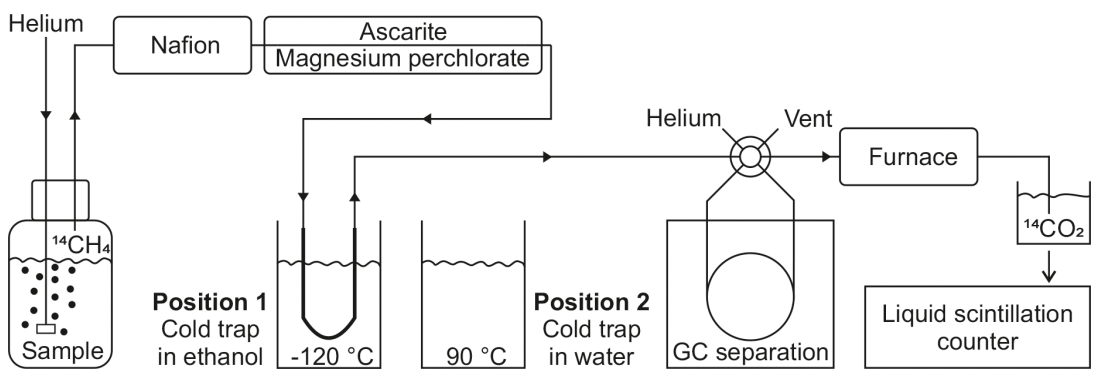

Figure 2. Schematic view of the methane stripping-oxidation line. Position 1 (displayed): the cold trap is placed in a $-120^{\circ} \mathrm{C}$ ethanol bath to retain the hydrocarbons. Position 2: the cold trap is transferred into a water bath at $90^{\circ} \mathrm{C}$ to release the hydrocarbons towards the gas chromatograph (GC). A detailed description is included in Sect. S2.

\section{Results and discussion}

\subsection{Subthermocline methane distribution}

Surface waters were oversaturated with methane with respect to the atmosphere at all stations (saturation values between $118 \%$ and $198 \%$ ) using the mean atmospheric methane concentrations for August 2016 obtained from atmospheric tower measurements at Utö (1919 ppb; position $59^{\circ} 46^{\prime} 50 \mathrm{~N}, 21^{\circ} 22^{\prime} 23 \mathrm{E}$; Juha Hatakka, Finnish Meterological Institute, personal communication, 2018). However, the eastern Gotland Basin had much higher maximum subthermocline methane concentrations than the western Gotland Basin (14.1 $\pm 6.1 \mathrm{nM}$ vs. $8.7 \pm 0.3 \mathrm{nM}$; Fig. 3). Such regional differences have previously been documented in the central Baltic Sea (Schmale et al., 2010, 2018; Jakobs et al., 2014).

Concentration profiles and stable carbon isotopes obtained in these earlier studies indicated that the subthermocline methane enrichments resulted from in situ production within the oxic water body. A transport from the deep anoxic waters was excluded because the methane from this pool is efficiently oxidized by aerobic methanotrophic bacteria situated in the oxic-anoxic transition zone at about $100 \mathrm{~m}$ water depth (Jakobs et al., 2013; Schmale et al., 2012, 2016). As their metabolism favours the turnover of ${ }^{12} \mathrm{CH}_{4}$, the remaining ${ }^{13} \mathrm{CH}_{4}$ becomes enriched and $\delta^{13} \mathrm{C} \mathrm{CH}_{4}$ values in the respective water layer are comparably high (e.g. $-40 \%$ in $80 \mathrm{~m}$ water depth; Jakobs et al., 2013). In the present study, subthermocline methane enrichments in the eastern Gotland Basin were characterized by strikingly depleted $\delta^{13} \mathrm{C} \mathrm{CH}_{4}$ values (-62.9\%o at $27 \mathrm{~m}$ at TF0271, Fig. 3), supporting the idea that the pronounced methane anomaly in this area originated from in situ biogenic production. In contrast, stable isotope ratios of methane in the upper water column of the western Gotland Basin showed $\delta^{13} \mathrm{C} \mathrm{CH}_{4}$ values of $-47.7 \%$ o at $20 \mathrm{~m}$ water depth (TF0284, Fig. 3) that are close to atmospheric equilibrium $(-47 \%$ ) .

Seasonal observations in the Baltic Sea revealed that the development of a thermocline, which functions as a barrier and limits fluxes to the atmosphere, was essential for the build-up of subthermocline methane enrichments (Jakobs (a) $\mathrm{T}\left[{ }^{\circ} \mathrm{C}\right], \mathrm{O}_{2}\left[\mathrm{ml} \mathrm{I}^{-1}\right]$,
$\mathrm{CH}_{4}[\mathrm{nM}]$ $\mathrm{T}\left[{ }^{\circ} \mathrm{C}\right], \mathrm{O}_{2}\left[\mathrm{ml} \mathrm{I}^{-1}\right]$,
$\mathrm{CH}_{4}[\mathrm{nM}]$
$\begin{array}{ccc}0 & 10 & 20\end{array} 30$ $\mathrm{T}\left[{ }^{\circ} \mathrm{C}\right], \mathrm{O}_{2}\left[\mathrm{ml} \mathrm{I}^{-1}\right]$,
$\mathrm{CH}_{4}[\mathrm{nM}]$
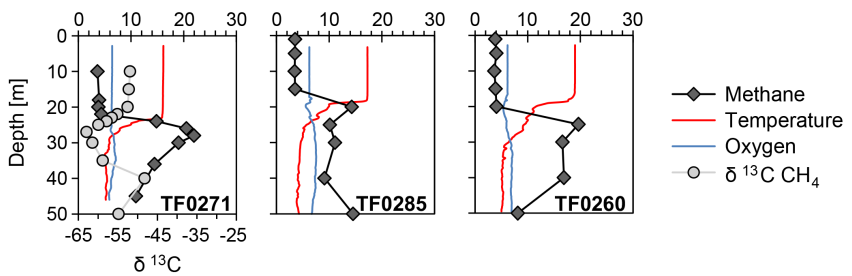

(b)
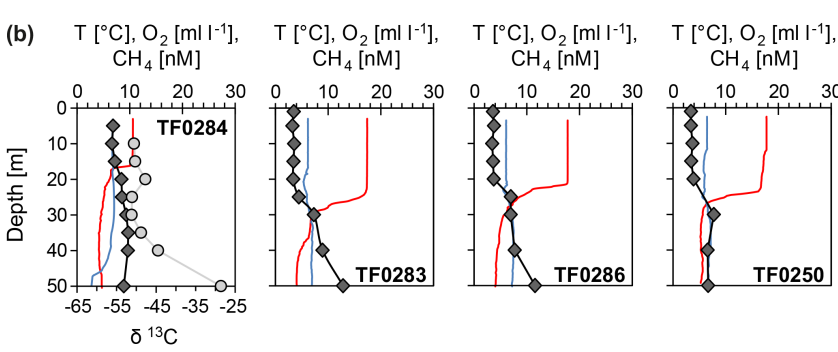

Figure 3. Vertical profiles of temperature $(T)$, oxygen $\left(\mathrm{O}_{2}\right)$ and methane $\left(\mathrm{CH}_{4}\right)$ concentrations in the central Baltic Sea: (a) stations with a distinct, and (b) stations without a distinct subthermocline methane enrichment; stable carbon isotope values of methane $\left(\delta^{13} \mathrm{C}\right)$ are presented for station TF0284 (western Gotland Basin) and TF0271 (eastern Gotland Basin).

et al., 2014; Schmale et al., 2018). Upwelling events can offset water column stratification through a replacement of warm, mostly nutrient-depleted surface water by cooler and usually nutrient-enriched subthermocline waters (Gidhagen, 1987; Lehmann and Myrberg, 2008; Reissmann et al., 2009). Such events may also cause a rapid decline in phytoplankton biomass in the surface water and affect the plankton composition (Vahtera et al., 2005; Nausch et al., 2009; Wasmund et al., 2012). Upwelling significantly increase surface water methane concentrations in the area around Gotland during the summer (Gülzow et al., 2013; Schneider et al., 2014). During our field campaign the sea surface temperature at station TF0284 in the western Gotland Basin dropped from 18 to $12^{\circ} \mathrm{C}$, as indicated by our oceanographic model output (Fig. 4; see also the temperature profile of station TF0284 in 


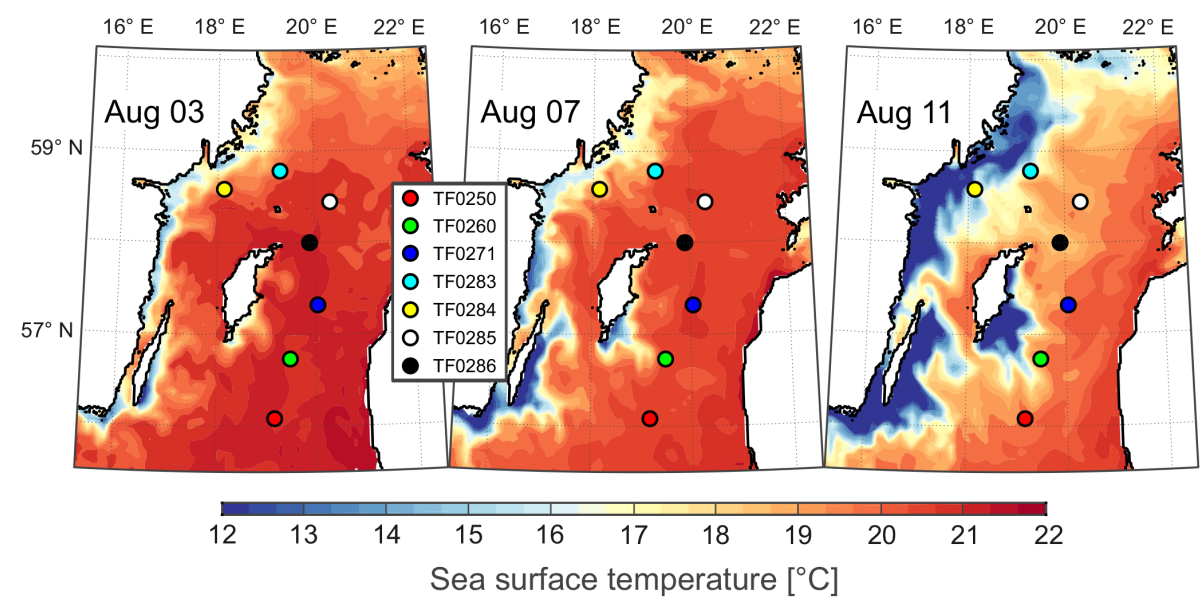

Figure 4. Development of sea surface temperatures in the central Baltic Sea between 3 and 11 August 2016 using the oceanographic model of Gräwe et al. (2015). The coloured dots represent the sampling stations.

(a) Subthermocline community
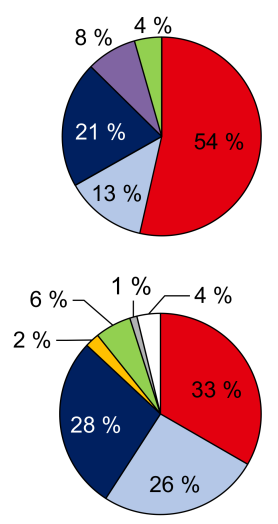

$\square$ Temora longicornis

$\square$ Acartia spp.

- Centropages spp.

$\square$ Eurytemora sp.

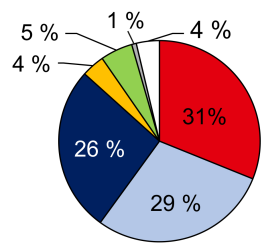

$\square$ Para-/ Pseudocalanaus spp.

$\square$ Cladocera

$\square$ Nauplii

Figure 5. Relative zooplankton community composition of the three zooplankton grazing experiments listed in Table 1. (a) Subthermocline (used in experiments 1-3) and (b) surface zooplankton community composition (used in experiment 1). Adults and copepodite stages $\mathrm{C} 1-\mathrm{C} 5$ were pooled for individual species, but Nauplii were pooled together for all copepod species.

Fig. 3). Assuming the thermocline was located at $18-20 \mathrm{~m}$ depth we estimated that the upwelled water masses must have had originated from a depth of 25-35 $\mathrm{m}$. Upwelling of cold, methane-rich subthermocline water can plausibly explain the strong surface water methane oversaturation observed at TF0284 (saturation value of $198 \%$ ). The other sta-

tions were not affected by upwelling events during the time of sampling. Even though our oceanographic model output indicated that the water mass at station TF0283 (sampled on 11 August) was located at the upwelling front (Fig. 4), our field measurements showed that the station was not affected by the event, as there is no drop in the surface water temperature visible (Fig. 3). However, our study indicates that in contrast to the deep water methane pool, which is efficiently separated from the surface water through the halocline at about $60 \mathrm{~m}$ depth (Schmale et al., 2010; Jakobs et al., 2014), upwelling of subthermocline waters has to be considered an important mechanism that contributes to the sea-air methane fluxes in the Baltic Sea.

\subsection{Controls on zooplankton associated methane production}

We obtained species- and food-specific methane production rates in incubations, which contained field copepods (surface and subthermocline communities, Fig. 5) in nearly natural abundances (1.5-8.5 times the natural density) by using the methane stripping-oxidation line. We found a substantial increase in methane production with the number of copepods in the incubations, but no production in controls containing phytoplankton only (Fig. 6). This implies that the production of methane is associated with the active grazing of zooplankton.

The incubations with a high proportion of $T$. longicornis had higher production rates than the Acartia spp. dominated setups ( $125 \pm 49$ vs. $84 \pm 19 \mathrm{fmol} \mathrm{CH}_{4}$ copepod $^{-1} \mathrm{~d}^{-1}$ ). This indicates that methane production may depend on the composition of the zooplankton community (Fig. 6a). However, the differences were not significant (Kruskall-Wallis test; $p=0.150, \mathrm{df}=1$ ), which may be a consequence of the limited number of incubations. Similar observations were made in laboratory experiments using cultured species from 
(a) Experiment 1

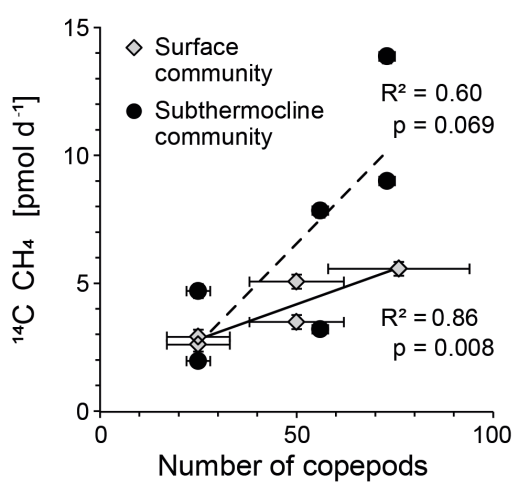

(b) Experiments 2 and 3

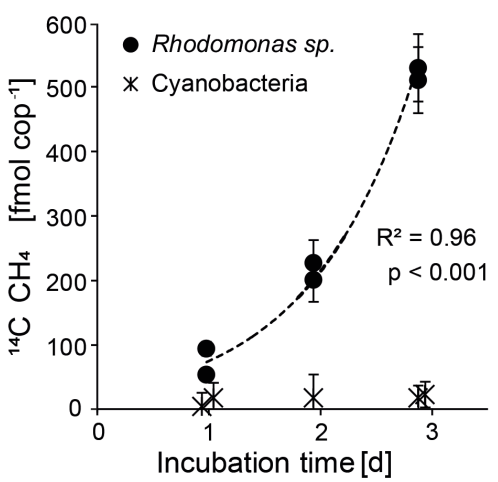

Figure 6. (a) Experiment 1: methane production as a function of the number of copepods in the surface (dominated by Acartia spp.) and subthermocline zooplankton communities (dominated by Temora longicornis). (b) Experiments 2 and 3: copepod-specific methane production over time when using the cryptophyte alga Rhodomonas sp. (experiment 2) or the cyanobacterium Nodularia spumigena (experiment 3 ) as food sources.

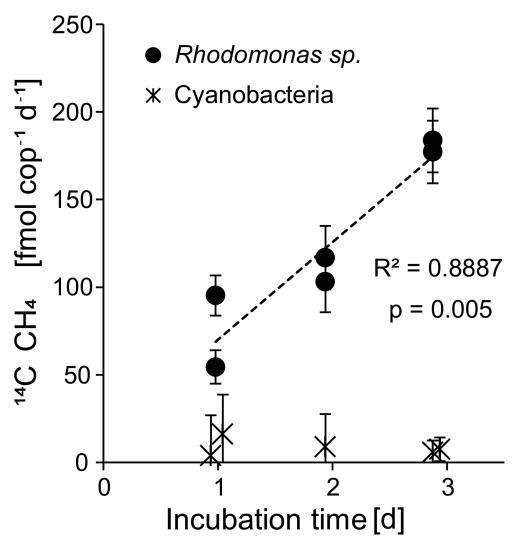

Figure 7. Experiments 2 and 3: copepod-specific methane production rates over time for the two food sources Rhodomonas sp. and cyanobacterium Nodularia spumigena.

the North Atlantic (de Angelis and Lee, 1994). These authors observed methane production in all experiments for T. longicornis grazing on phytoplankton, but not for Acartia tonsa. These differences may be due to species-specific differences in grazing rates, food preferences and gut floras. Furthermore, the methane production rates per copepod reported by de Angelis and Lee (1994) were 2 orders of magnitude higher (4-20 $\mathrm{pmol} \mathrm{CH}_{4}$ copepod $^{-1} \mathrm{~d}^{-1}$ ) than the rates measured in our experiments. Still, our results are in agreement with those of previous zooplankton incubation experiments conducted in the central Baltic Sea (0.3 pmol $\mathrm{CH}_{4}$ copepod $^{-1} \mathrm{~d}^{-1}$, Schmale et al., 2018). This similarity is notable as the previous experiments used zooplankton abundances that were about 1000 times higher than the natural density in the field. The obvious discrepancy from the methane production rates reported by de Angelis and Lee (1994) might be related to the physiological differ- ences (e.g. animal size) between the copepods used (length $T$. longicornis North Atlantic: $1300 \mu \mathrm{m}$ vs. Baltic Sea: $700 \mu \mathrm{m}$ ). The methane production rates may also be lower for younger development stages of copepods, which contributed to the natural surface community used in our incubations (Fig. 5). Animal size affects the oxygen gradient in the guts of these copepods and affects the dimension of produced fecal pellets and, thus, the penetration depth of oxygen into the pellet (Ploug and Jörgensen, 1999; Tang et al., 2011). Alternatively, lower methane production rates observed in our experiments may have reflected a response of the animals to stress of being removed from their natural environment. In contrast to the study of de Angelis and Lee (1994), who used cultured animals in their experiments, we immediately transferred the field copepods into incubation bottles and fed phytoplankton that were not representative of the phytoplankton biomass of the Baltic Sea (i.e. the cryptophyte Rhodomonas sp.) and thus did not belong to their natural food source. To lower the capture stress, we selected a rather gentle method for sampling, and we avoided food shortage, which was shown to be more influential on the decrease in physiological rates (Ikeda and Skjoldal, 1980). Also, we used a food source which was previously shown to be of good quality (e.g. Knuckey et al., 2005; Koski and Breteler, 2003). Another factor which may have led to lower methane production rates than measured by de Angelis and Lee (1994) is the quality of the filtered seawater used in the incubations. In our experiments we used filters with a pore size of $0.2 \mu \mathrm{m}$, while de Angelis and Lee (1994) used filters with a pore size of $1.2 \mu \mathrm{m}$ to prepare the incubation water. Our intention was to exclusively investigate the methane production by zooplankton while minimizing the influence of particulate material (e.g. fecal pellets) in the seawater. However, we are aware that the smaller pore size used in our studies reduced the number of bacteria in the incubation water, which may have been important for the methane production outside the body of the copepods. 
(a) TF0271 (0-10 m)

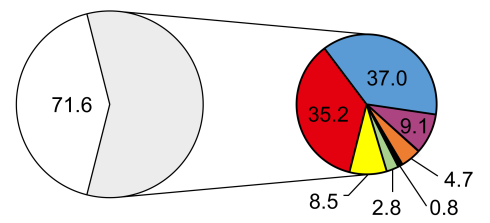

(b) TF0284 (0-10 m)

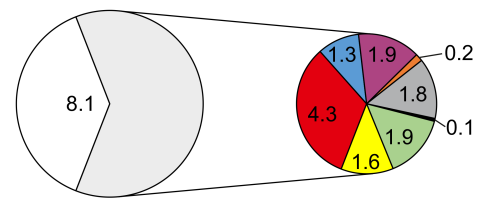

(c) TF0286 (0-10 m)

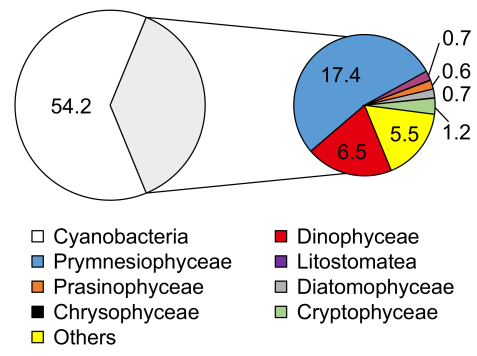

Figure 8. Surface phytoplankton community composition integrated over the upper $10 \mathrm{~m}$ of the water column $\left(\mathrm{mg} \mathrm{C} \mathrm{m}^{-3}\right)$ at stations with a distinct (a) and without a distinct (b, c) subthermocline methane enrichment. The grey shaded non-cyanobacteria community is described in detail in the coloured circles.

Measurable methane production occurred when the $T$. longicornis-dominated community was fed on Rhodomonas sp., while no production occurred when it was fed on the cyanobacterium N. spumigena (Fig. 6b). In fact it appears that these cyanobacteria are a rather negligible food source for planktonic herbivores due to their toxic properties, large size, and low lipide concentrations (Sellner et al., 1994; Eglite et al., 2018). Our experiments therefore reveal that the availability of a suitable phytoplankton diet is an important control on the zooplankton-associated methane production.

The observed exponential increase in methane with increasing incubation time implies that zooplankton-associated methane production is a continuous process (Fig. $6 \mathrm{~b}$ ). In addition, we measured a linear increase in the methane production rates per individual with increasing incubation time (Fig. 7). Potential explanations include (1) a delay in grazing by stress through experimental conditions, (2) the accumulation of fecal pellets within the incubation bottles followed by methane production in anoxic microenvironments, and (3) enhanced methane production through release of methane precursor substances from fecal pellets or from disrupted phytoplankton cells into the incubation water. In the first case we would expect the production rates to stabilize within the 3 days of the experiment; instead, we observed a linear increase and a rather low variability among the replicates. In the second case, the fecal pellets could temporarily act as anoxic microenvironments for methanogenic archaea (Oremland et al., 1979; Bianchi et al., 1992; Marty et al., 1993; Karl and Tilbrook, 1994; Ditchfield et al., 2012). However, it is debatable whether anoxic conditions can persist within fecal pellets outside of the anoxic digestive tracts of the copepods (Ditchfield et al., 2012; Ploug et al., 2008). For T. longicornis fed on Rhodomonas sp., the diffusive boundary layer of the fecal pellets through which the exchange of gases occurs was shown to be very thin, and no indications of anoxic conditions were detected (Ploug et al., 2008). Studies investigating the anoxic potential within particle aggregates were only able to confirm anoxic conditions in the interior of nutrient- and carbon-rich particles $>600 \mu \mathrm{m}$ and suggest that anoxia in marine aggregates is more likely to occur in an oxygen-depleted water column (Ploug et al., 1997; Ploug et al., 2001). On our cruise, a fecal pellet size of only $<150 \mu \mathrm{m}$ was measured for the surface and subthermocline zooplankton communities. We therefore suggest that anaerobic methanogenesis by archaea thriving within fecal pellets played only a minor role. Instead, continuous release of methanogenic substrates (like organic sulfur compounds) by cell disruption during feeding, defecation, or diffusion from fecal pellets may have resulted in an enrichment of these substances in the incubation water, and fostered a subsequent microbial turnover of these precursors outside the body of the copepod.

\subsection{Organic sulfur compounds as possible substrates for methane production in oxic waters}

The phytoplankton community composition in the surface (Fig. 8) and subthermocline waters (Fig. 9) was similar at all investigated stations during our field campaign. However, the phytoplankton biomass was lower at station TF0284, which was recently influenced by an upwelling event. Hence, it needs to be considered that also the phytoplankton composition at this station could have been altered by the event. Dinophyceae, in particular the mixotrophic Dinophysis norvegica, were more abundant at stations with a distinct subthermocline methane enrichment. They produce relatively high amounts of DMSP and DMSO compared to the other phytoplankton species observed within our study (Keller et al., 1989; Hatton and Wilson, 2007; Caruana and Malin, 2014). Also, positive correlations have previously been observed between DMSP and $\mathrm{CH}_{4}$ and DMSO and $\mathrm{CH}_{4}$ in the surface ocean (Zindler et al., 2013). Damm et al. (2010) suggested that the microbial metabolization of DMSP and its degradation products dimethylsulfide (DMS) and methanethiol to methane is favoured under nitrogen-stressed conditions in oligotrophic waters. In the central Baltic Sea the dissolved inorganic nitrogen pool that builds up over the winter months is already exhausted after the first spring bloom in the photic zone and leaves behind nitrogen-stressed conditions for phytoplankton taxa, which are unable to fix molecular nitrogen (Schneider et al., 2009). These nitrogen-stressed conditions 
(a) TF0271 (12.8., $20 \mathrm{~m})$

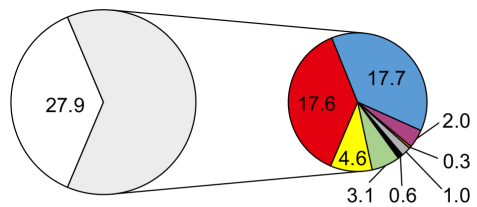

(b) TF0271 (12.8., $21 \mathrm{~m})$

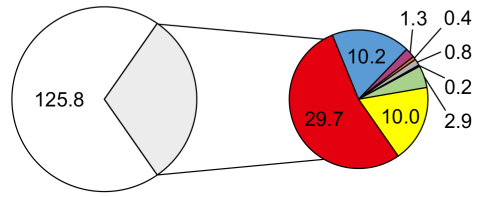

(c) TF0271 (18.8., $20 \mathrm{~m})$

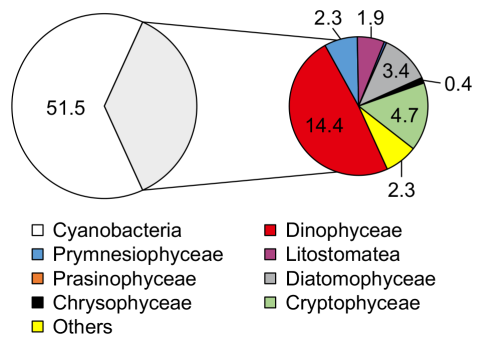

(d) TF0260 (25 m)

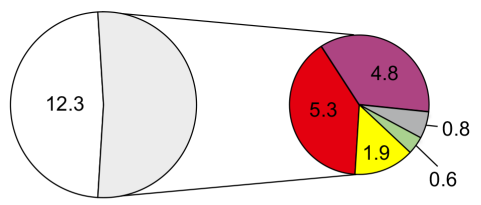

(e) TF0285 (22 m)

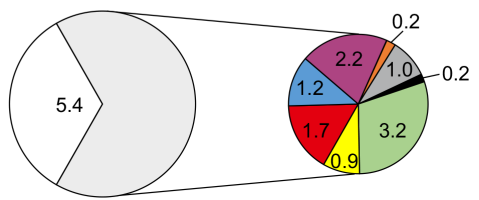

(f) TF0286 (22 m)

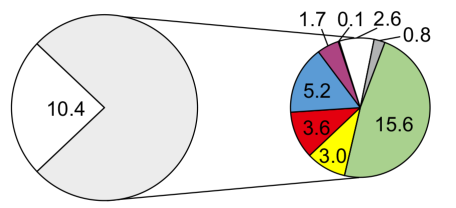

Figure 9. Phytoplankton community composition within the subthermocline chlorophyll $a$ maximum $\left(\mathrm{mg} \mathrm{C} \mathrm{m}^{-3}\right)$ at three stations with a distinct subthermocline methane enrichment (a-e) and at one station without a distinct enrichment (f). The grey shaded non-cyanobacteria community is described in detail in the coloured circles. Three replicate samples were taken at TF0271 in a period of 7 days (a-c) showing that the prevalence of Dinophyceae below the thermocline is a consistent feature at this station.

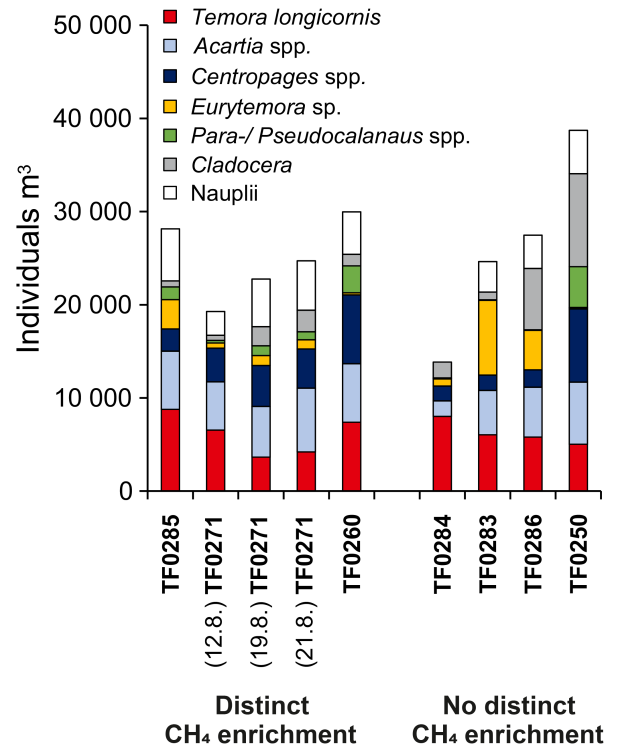

Figure 10. Average zooplankton community composition between the sea surface and the halocline for stations with distinct (left bars) and without distinct (right bars) subthermocline methane enrichments. Three replicate samples were taken at station TF0271 in a period of 10 days to investigate the temporal variability in the community composition at this location. can lead to an accumulation of DMSP in phytoplankton cells (Sunda et al., 2007) that exceeds $10 \%$ of the cell carbon (Matrai, 1994). In the central Baltic Sea a pronounced DMS maximum was detected during summer months in the surface waters (Leck et al., 1990). No correlation was identified between high DMS concentrations and any particular phytoplankton species. Instead, DMS production in the surface water was accelerated through phytoplankton growth under nitrogen-limited conditions, and correlated significantly with copepod and total zooplankton biomass. Hence, the release of DMSP, DMSO and DMS from phytoplankton was suggested to be controlled by zooplankton and heterotrophic bacteria (Leck et al., 1990; Kwint et al., 1996; Wolfe et al., 1997; Simo et al., 2002; Lee et al., 2003).

Similar to phytoplankton, zooplankton, in particular copepods, may use DMSP for osmoregulation and were shown to increasingly assimilate DMSP at higher salinities (Tang et al., 1999). Likewise, DMSP ingestion by copepods increased with increasing DMSP content of the food (Tang et al., 1999). De Angelis and Lee (1994) showed that T. longicornis feeding on Dinophyceae (Prorocentrum minimum) resulted in the highest methane production rates per copepod, which suggests a link between the DMSP/DMSO content of the diet and zooplankton-associated methane production. Based on the observed zooplankton and phytoplankton distributions (Figs. 8, 9 and 10), we speculate that the development of distinct subthermocline methane enrichments in the central 

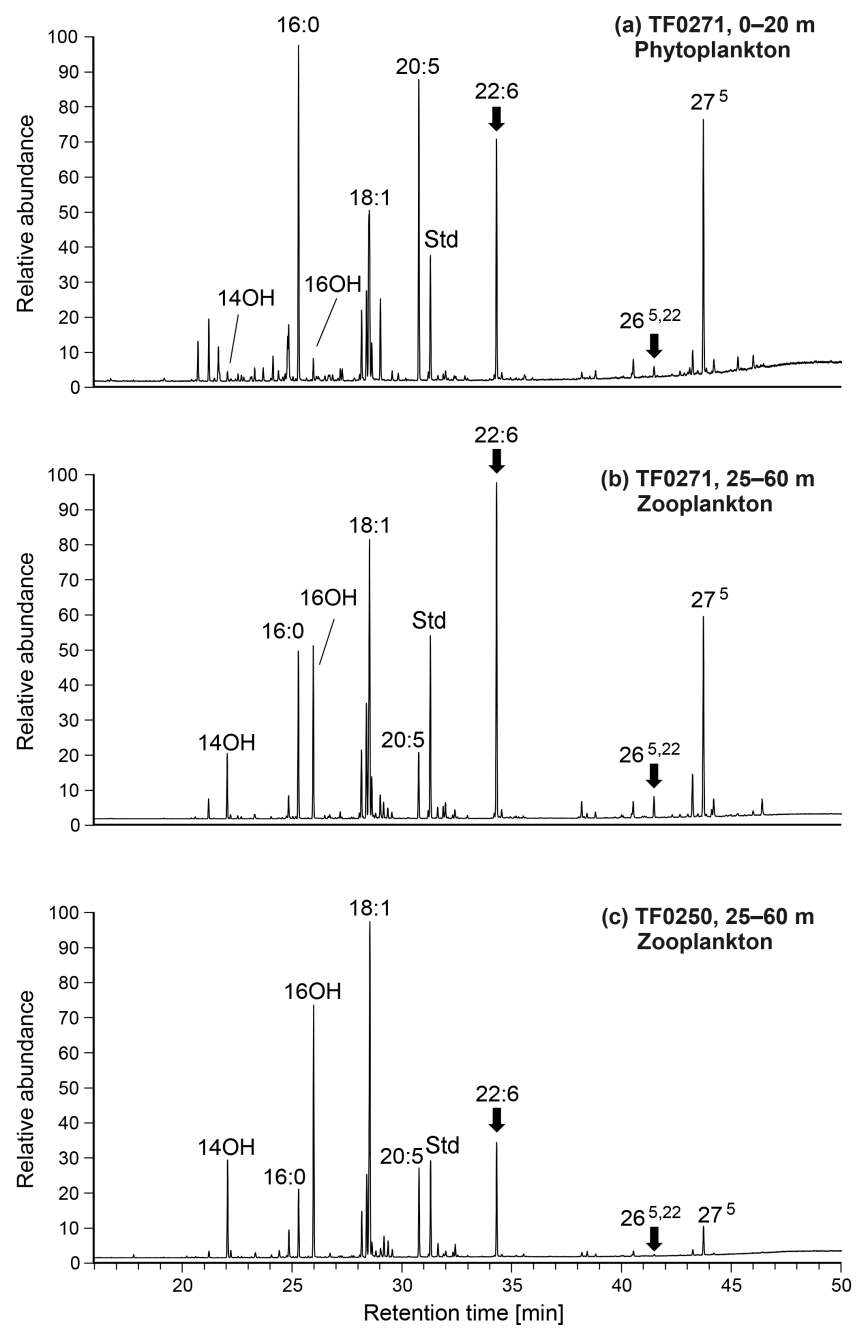

Figure 11. GC-MS chromatograms of neutral lipids (methyl ester/TMS derivatives) from mixed-layer phytoplankton (a) and subthermocline zooplankton (b) at station TF0271 (with a distinct subthermocline methane enrichment). Data from subthermocline zooplankton at TF0250 (without a distinct subthermocline methane enrichment) are shown as a reference (c). Main compounds are labelled and interpreted as follows (see text for further discussion); 16:0, $n$-hexadecanoic acid (unspecific, high in bacteria); $14 \mathrm{OH} / 16 \mathrm{OH}, n$-tetradecanol and $n$-hexadecanol (copepod wax esters); 18:1, oleic acid (unspecific, high in heterotrophs but also in (cyano)bacteria); 20:5, $n$-eicosapentaenoic acid (phytoplankton, high in diatoms); Std, internal standard; 22:6, $n$-docosahexaenoic acid (phytoplankton, high in Dinophyceae); $26^{5,22}, 24$-norcholesta5,22-dien-3 $\beta$-ol (specific for Dinophyceae); $27^{5}$, cholesterol (unspecific, high in zooplankton, but also found in some algae including Dinophyceae). Compounds indicating contributions from Dinophyceae-derived lipids are highlighted with an arrow. Note enhanced levels of these biomarkers in T. longicornis-dominated zooplankton at the station with a distinct subthermocline methane enrichment (TF0271).

Baltic Sea is influenced by the combination of T. longicornis and relatively high abundances of Dinophyceae.
To retrieve further information about potential trophic relationships between T. longicornis and Dinophyceae, lipid biomarkers of concentrated plankton samples from two depths, the surface layer and subthermocline waters were analysed. Also, samples from stations with (TF0271) and without (TF0250) distinct subthermocline methane enrichment were compared. Although individual fatty acids have to be assigned cautiously to specific taxonomic groups, the distribution of these compounds in copepod neutral lipids has been shown to largely reflect the lipid composition of the prey (Peters et al., 2013). Figure 11a shows the neutral lipids extracted from the surface-layer phytoplankton obtained at station TF0271. The fatty acids contained in samples from this depth revealed major contributions from cyanobacteria (typically high in 16:0 and $\mathrm{C}_{18}$ fatty acids), diatoms (high in 20:5), and Dinophyceae (22:6; cf. Peters et al., 2013), which corresponds to the phytoplankton community composition observed at this station by microscopy (Fig. 8a). The relatively high abundance of Dinophyceae in the surface layer was further reflected in the presence of 24-norcholesta-5,22dien- $3 \beta$-ol $\left(26^{5,22}\right)$, an unusual sterol that is regarded as a specific marker for these algae in temperate waters (Rampen et al., 2007).

Compounds extracted from the subthermocline zooplankton community at station TF0271, dominated by T. longicornis $(52 \%)$, revealed a broad similarity to the phytoplanktonderived lipids, and reflected the diurnal feeding behaviour of these copepods in the surface mixed layer (Fig. 11b). Notably though, lipids of putative dinophyte origin were considerably enriched, supporting the idea of a preferential uptake of these algae by $T$. longicornis. In contrast, mixed zooplankton obtained at reference station TF0250 contained few T. longicornis (10\%) but relatively more Acartia spp. (37\%) and Pseudocalanus spp. (32\%). This sample showed much lower relative amounts of the Dinophyceae-derived biomarkers $22: 6 \omega 3$ and $26^{5,22}$, indicating only a minor importance of this food source at the reference station (Fig. 11c). Altogether, our biomarker data further corroborate our suggestion that the feeding of T. longicornis on (DMSP/DMSO-rich) Dinophyceae may be an essential factor in the development of subthermocline methane enrichments in the central Baltic Sea.

We further assume that zooplankton-associated production of fecal pellets and the transit of these pellets through the water column play a critical role in the build-up of the pool of organic sulfur compounds in the central Baltic Sea. Sinking velocities are low for pellets produced from Dinophyceae (Hansen and Bech, 1996; Thor et al., 2003). Hence, we propose that high degradation rates of those fecal pellets and an efficient microbial turnover of the contained organic sulfur compounds (e.g. DMSP; Tang, 2001) contribute to the subthermocline methane enrichment. The gradual loss of organic sulfur compounds from fecal pellets could plausibly explain the increase in copepod-specific methane production over time, as measured in our incubation study (Figs. $6 \mathrm{~b}$ and 
7). Unfortunately, no Dinophyceae culture was available for our field experiments, because of their relatively low growth rates (Carpenter et al., 1995) and mixotrophic feeding requirements (Tong et al., 2010) that did not allow an adequate radio labelling of the culture with sodium bicarbonate. Likewise, the relatively low production rates observed in our experiments could be explained by the lack of appropriate substrates for methane production, as Cryptophyceae (i.e. Rhodomonas sp.) contain only low amounts of DMSP as compared to other phytoplankton groups (Dong et al., 2013). Furthermore, we used $0.2 \mu \mathrm{m}$ filtered seawater in our incubations, which was depleted in microorganisms. However, these microorganisms might be relevant for the turnover of DMSP to methane outside of the copepod bodies.

\section{Summary and conclusions}

Several processes that produce methane in oxic waters have been recently identified and it is assumed that climate change will impact their source strength, with far-reaching consequences for methane flux and climate feedback. However, mechanisms and magnitudes of these sources remain vague. Based on our findings, we conclude that zooplankton contributes to subthermocline methane enrichments in the central Baltic Sea by (1) direct methane production within the digestive track of copepods and/or (2) indirect contribution to methane production through release of methane precursor substances into the surrounding water, followed by microbial degradation to methane outside the copepod's body. Further, our field observations combined with lipid biomarker studies indicate that a distinct food web segment consisting of DMSP-rich Dinophyceae and the copepod T. longicornis may foster the build-up of methane anomalies in oxic waters of the central Baltic Sea. For future studies, we recommend using unfiltered in situ water for the incubations. We further suggest cultivating Dinophyceae under controlled laboratory conditions before the field campaign and feeding these radiolabelled organisms to in situ copepods directly after sampling in the field. These incubations should be accompanied by a quantification of the DMSP and DMS content in phytoplankton and zooplankton as well as in the water column.

Data availability. The data presented here are included in the Supplement.

Supplement. The supplement related to this article is available online at: https://doi.org/10.5194/bg-16-1-2019-supplement.

Author contributions. BS, OS, and SO designed and built the methane stripping-oxidation line and performed the incubation experiments. JW and NLW supported the plankton sampling and the grazing experiments. VT and AKW conducted the lipid biomaker analysis. UG performed the oceanographic modelling of the upwelling event. SS performed the stable carbon isotope analyses. GR, ML, and NW helped with the data analyses and interpretation. All the authors co-wrote the manuscript.

Competing interests. The authors declare that they have no conflict of interest.

Acknowledgements. We thank Nicole C. Power Guerra for her help at sea and in the laboratory. We would also like to thank Michael Glockzin for producing the map and Juha Hatakka (Finnish Meteorological Institute) for providing the atmospheric methane concentration data from station Utö. Further, we appreciate the critical comments by Jörg Dutz. We thank the captain and crew of R/V Alkor for technical support. This work was supported by the German Research Foundation (DFG) through grant SCHM 2530/5-1 to Oliver Schmale, DFG grant LA 1466/10-1 to Matthias Labrenz, and DFG grant LO 1820/4-1 to Natalie Loick-Wilde.

The publication of this article was funded by the Open Access Fund of the Leibniz Association.

Edited by: Helge Niemann

Reviewed by: Susan Mau and one anonymous referee

\section{References}

Bange, H. W., Bartell, U. H., Rapsomanikis, S., and Andreae, M. O.: Methane in the Baltic and Noth Seas and a reassessment of the marine emission of methane, Global Biogeochem. Cy., 8, 465480, 1994.

Berggreen, U., Hansen, B., and Kiørboe, T.: Food size spectra, ingestion and growth of the copepod Acartia tonsa during development: Implications for determination of copepod production, Mar. Biol., 99, 341-352, 1988.

Bianchi, M., Marty, D., Teyssié, J.-L., and Fowler, S. W.: Strictly aerobic and anaerobic bacteria associated with sinking particulate matter and zooplankton fecal pellets, Mar. Ecol. Prog. Ser., 88, 55-60, 1992.

Carpenter, E. J., Janson, S., Boje, R., Pollehne, F., and Chang, J.: The dinoflagellate Dinophysis norvegica: biological and ecological observations in the Baltic Sea, Eur. J. Phycol., 30, 1-9, 1995.

Caruana, A. M. N. and Malin, G.: The variability in DMSP content and DMSP lyase activity in marine dinoflagellates, Prog. Oceanogr., 410-424, 120, 2014.

Damm, E., Helmke, E., Thoms, S., Schauer, U., Nöthig, E., Bakker, K., and Kiene, R. P.: Methane production in aerobic oligotrophic surface water in the central Arctic Ocean, Biogeosciences, 7, 1099-1108, https://doi.org/10.5194/bg-7-1099-2010, 2010.

De Angelis, M. A. and Lee, C.: Methane production during zooplankton grazing on marine phytoplankton, Limnol. Oceanogr., 39, 1298-1308, 1994.

Ditchfield, A. K., Wilson, S. T., Hart, M. C., Purdy, K. J., Green, D. H., and Hatton, A. D.: Identification of putative methylotrophic and hydrogenotrophic methanogens within sedimenting material 
and copepod faecal pellets, Aquat. Microb. Ecol., 67, 151-160, 2012.

Dong, Y., Yang, G.-P., and Tang, K. W.: Dietary effects on abundance and carbon utilization ability of DMSP-consuming bacteria associated with the copepod Acartia tonsa Dana, Mar. Biol. Res., 9, 809-814, 2013.

Donis, D., Flury, S., Stöckli, A., Spangenberg, J. E., Vachon, D., and McGinnis, D. F.: Full-scale evaluation of methane production under oxic conditions in a mesotrophic lake, Nat. Commun., 8, 1661, https://doi.org/10.1038/s41467-017-01648-4, 2017.

Dutz, J., Koski, M., and Jónasdóttir, S. H.: Copepod reproduction is unaffected by diatom aldehydes or lipid composition, Limnol. Oceanogr., 53, 225-235, 2008.

Eglite, E., Wodarg, D., Dutz, J., Wasmund, N., Nausch, G., Liskow, I., Schulz-Bull, D., and Loick-Wilde, N.: Strategies of amino acid supply in mesozooplankton during cyanobacteria blooms: a stable nitrogen isotope approach, Ecosphere, 9, e02135, https://doi.org/10.1002/ecs2.2135, 2018.

Etminan, M., Myhre, G., Highwood, E. J., and Shine, K. P.: Radiative forcing of carbon dioxide, methane, and nitrous oxide: A significant revision of the methane radiative forcing, Geophys. Res. Lett., 43, 12614-12623, https://doi.org/10.1002/2016GL071930, 2016.

Feistel, R., Nausch, G., and Wasmund, N.: State and evolution of the Baltic Sea, 1952-2005: a detailed 50-year survey of meteorology and climate, physics, chemistry, biology, and marine environment, John Wiley \& Sons, New Jersey, 2008.

Franck, H., Matthäus, W., and Sammler, W.: Major inflows of saline water into the Baltic Sea during the present century, Gerl. Beitr. Geophys., 96, 517-531, 1987.

Gidhagen, L.: Coastal upwelling in the Baltic Sea - Satellite and in situ measurements of sea-surface temperatures indicating coastal upwelling, Estuar. Coast. Shelf Sci., 24, 449-462, 1987.

Gräwe, U., Holtermann, P., Klingbeil, K., and Burchard, H.: Advantages of vertically adaptive coordinates in numerical models of stratified shelf seas, Ocean Model., 92, 56-68, 2015.

Grossart, H. P., Frindte, K., Dziallas, C., Eckert, W., and Tang, K. W.: Microbial methane production in oxygenated water column of an oligotrophic lake, P. Natl. Acad. Sci. USA, 108, 1965719661, 2011.

Guillard, R. R. L. and Ryther, J. H.: Studies of marine diatoms. I. Cyclotella nana Husdedt and Detonula confervacea (Cleve) Gran., Can. J. Microbiol., 8, 229-239, 1962.

Gülzow, W., Rehder, G., Schneider v. Deimling, J., Seifert, T., and Tóth, Z.: One year of continuous measurements constraining methane emissions from the Baltic Sea to the atmosphere using a ship of opportunity, Biogeosciences, 10, 81-99, https://doi.org/10.5194/bg-10-81-2013, 2013.

Hällfors, H., Hajdu, S., Kuosa, H., and Larsson, U.: Vertical and temporal distribution of the dinoflagellates Dinophysis acuminata and D. norvegica in the Baltic Sea, Boreal Environ. Res., 16, 121-135, 2011.

Hansen, B. and Bech, G.: Bacteria associated with a marine planktonic copepod in culture. I. Bacterial genera in seawater, body surface, intestines and fecal pellets and succession during fecal pellet degradation, J. Plankton Res., 18, 257-273, 1996.

Hansen, F. C., Möllmann, C., Schütz, U., and Neumann, T.: Spatiotemporal distribution and production of calanoid copepods in the central Baltic Sea, J. Plankton Res., 28, 39-54, 2006.
Hatton, A. D. and Wilson, S. T.: Particulate dimethylsulphoxide and dimethylsulphoniopropionate in phytoplankton cultures and Scottish coastal waters, Aquat. Sci., 69, 330-340, 2007.

HELCOM: Manual for marine monitoring in the COMBINE programme of HELCOM, last updated July 2017, available at: http://www.helcom.fi/Documents/Action areas/Monitoring and assessment/Manuals and Guidelines/, last access: February 2018.

Holmes, M. E., Sansone, F. J., Rust, T. M., and Popp, B. N.: Methane production, consumption, and air-sea exchange in the open ocean: An Evaluation based on carbon isotopic ratios, Global Biogeochem. Cy., 14, 1-10, 2000.

Ikeda, T. and Skjoldal, H. R.: The effect of laboratory conditions on the extrapolation of experimental measurements to the ecology of marine zooplankton VI. Changes in physiological activities and biochemical components of Acetes sibogae australis and Acartia australis after capture, Mar. Biol., 58, 285-293, 1980.

IPCC: Climate Change 2013: The Physical Science Basis. Contribution of Working Group I to the Fifth Assessment Report of the Intergovernmental Panel on Climate Change, edited by: Stocker, T. F., Qin, D., Plattner, G.-K., Tigno, M., Allen, S. K., Boschung, J., Nauels, A., Xia, Y., Bex, and Midgley, P. M., Cambridge University Press, Cambridge (UK) and New York (USA), 1535 pp., 2013.

Jakobs, G., Rehder, G., Jost, G., Kießlich, K., Labrenz, M., and Schmale, O.: Comparative studies of pelagic microbial methane oxidation within the redox zones of the Gotland Deep and Landsort Deep (central Baltic Sea), Biogeosciences, 10, 7863-7875, https://doi.org/10.5194/bg-10-7863-2013, 2013.

Jakobs, G., Holtermann, P., Berndmeyer, C., Rehder, G., Blumenberg, M., Jost, G., Nausch, G., and Schmale, O.: Seasonal and spatial methane dynamics in the water column of the central Baltic Sea (Gotland Sea), Cont. Shelf Res., 91, 12-25, 2014.

Karl, D. M. and Tilbrook, B. D.: Production and transport of methane in oceanic particulate organic matter, Nature, 368, 732734, 1994.

Karl, D. M., Beversdorf, L., Bjorkman, K. M., Church, M. J., Martinez, A., and Delong, E. F.: Aerobic production of methane in the sea, Nat. Geosci., 1, 473-478, 2008.

Keller, M. D., Bellows, W. K., and Guillard, R. R. L.: Dimethyl Sulfide Production in Marine Phytoplankton, in: Biogenic Sulfur in the Environment, ACS Symposium Series, 393, Am. Chem. S., 167-182, 1989.

Keppler, F., Hamilton, J. T. G., Braß, M., and Röckmann, T.: Methane emissions from terrestrial plants under aerobic conditions, Nature, 439, 187-191, 2006.

Knuckey, R. M., Semmens, G. L., Mayer, R. J., and Rimmer, M. A.: Development of an optimal microalgal diet for the culture of the calanoid copepod Acartia sinjiensis: Effect of algal species and feed concentration on copepod development, Aquaculture, 249, 339-351, 2005.

Koski, M. and Breteler, W. C. M. K.: Influence of diet on copepod survival in the laboratory, Mar. Ecol.-Prog. Ser., 264, 73-82, 2003.

Kwint, R. L. J., Irigoien, X., and Kramer, J. M.: Copepods and DMSP, in: Biological and environmental chemistry of DMSP and related sulfonium compounds, edited by: Kiene, R. P., Visscher, P. T., Keller, M. D., and Kirst, G. O., Plenum Press, New York, 239-252, 1996. 
Lamontagne, R. A., Swinnerton, J. W., Linnenbom, V. J., and Smith, W. D.: Methane concentrations in various marine environments, J. Geophys. Res., 78, 5317-5324, 1973.

Leck, C., Larsson, U., Bågander, L. E., Johansson, S., and Hajdu, S.: Dimethyl sulfide in the Baltic Sea: Annual variability in relation to biological activity, J. Geophys. Res.-Oceans, 95, 3353-3363, 1990.

Lee, P. A., Saunders, P. A. J., de Mora, S., Deibel, D., and Levasseur, M.: Influence of copepod grazing on concentrations of dissolved dimethylsulfoxide and related sulfur compounds in the North Water, northern Baffin Bay, Mar. Ecol.-Prog. Ser., 255, 235-248, 2003.

Lehmann, A. and Myrberg, K.: Upwelling in the Baltic Sea - A review, J. Marine Syst., 74, S3-S12, 2008.

Lenhart, K., Bunge, M., Ratering, S., Neu, T. R., Schuttmann, I., Greule, M., Krammann, C., Schnell, S., Müller, C., Zorn, H., and Keppler, F.: Evidence for methane production by saprotrophic fungi, Nat. Commun., 3, 1046, https://doi.org/10.1038/ncomms2049, 2012.

Lenhart, K., Weber, B., Elbert, W., Steinkamp, J., Clough, T., Crutzen, P., Pöschl, U., and Keppler, F.: Nitrous oxide and methane emissions from cryptogamic covers, Glob. Change Biol., 21, 3889-3900, 2015.

Lenhart, K., Klintzsch, T., Langer, G., Nehrke, G., Bunge, M., Schnell, S., and Keppler, F.: Evidence for methane production by the marine algae Emiliania huxleyi, Biogeosciences, 13, 3163 3174, https://doi.org/10.5194/bg-13-3163-2016, 2016.

Marty, D. G.: Methanogenic bacteria in seawater, Limnol. Oceanogr., 38, 452-456, 1993.

Matrai, P. A. and Keller, M. D.: Total organic sulfur and dimethylsulfoniopropionate in marine phytoplankton: intracellular variations, Mar. Biol., 119, 61-68, 1994.

Mohrholz, V., Naumann, M., Nausch, G., Krüger, S., and Gräwe, U.: Fresh oxygen for the Baltic Sea - An exceptional saline inflow after a decade of stagnation, J. Marine Syst., 148, 152-166, 2015.

Nausch, M., Nausch, G., Lass, H. U., Mohrholz, V., Nagel, K., Siegel, H., and Wasmund, N.: Phosphorus input by upwelling in the eastern Gotland Basin (Baltic Sea) in summer and its effects on filamentous cyanobacteria, Estuar. Coast. Shelf Sci., 83, 434-442, 2009.

Nieuwenhuize, J., Maas, Y. E. M., and Middelburg, J. J.: Rapid analysis of organic carbon and nitrogen in particulate materials, Mar. Chem., 45, 217-224, 1994.

Olenina, I., Hajdu, S., Andersson, A., Edler, L., Wasmund, N., Busch, S., Göbel, J., Gromisz, S., Huseby, S., Huttunen, M., Jaanus, A., Kokkonen, P., Ledaine, I., Niemkiewicz, E.: Biovolumes and size-classes of phytoplankton in the Baltic Sea, Baltic Sea Environment Proceedings, 106, 1-144, 2006.

Omstedt, A., Elken, J., Lehmann, A., and Piechura, J.: Knowledge of the Baltic Sea physics gained during the BALTEX and related programmes, Prog. Oceanogr., 63, 1-28, 2004.

Oremland, R. S.: Methanogenic activity in plankton samples and fish intestines: A mechanism for in situ methanogenesis in oceanic surface waters, Limnol. Oceanogr., 24, 1136-1141, 1979.

Peters, J., Dutz, J., and Hagen, W.: Trophodynamics and life-cycle strategies of the copepods Temora longicornis and Acartia lon- giremis in the Central Baltic Sea, J. Plankton Res., 35, 595-609, 2013.

Ploug, H.: Small-scale oxygen fluxes and remineralization in sinking aggregates, Limnol. Oceanogr., 46, 1624-1631, 2001.

Ploug, H. and Jørgensen, B. B.: A net-jet flow system for mass transfer and microsensor studies of sinking aggregates, Mar. Ecol.-Prog. Ser., 176, 279-290, 1999.

Ploug, H., Kühl, M., Buchholz-Cleven, B., and Jörgensen, B. B.: Anoxic aggregates - an ephemeral phenomenon in the pelagic environment?, Aquat. Microb. Ecol., 13, 285-294, 1997.

Ploug, H., Iversen, M. H., and Fischer, G.: Ballast, sinking velocity, and apparent diffusivity within marine snow and zooplankton fecal pellets: Implications for substrate turnover by attached bacteria, Limnol. Oceanogr., 53, 1878-1886, 2008.

Rampen, S. W., Schouten, S., Abbas, B., Elda Panoto, F., Muyzer, G., Campbell, C. N., Fehling J., and Sinninghe Damsteì, J. S.: On the origin of 24-norcholestanes and their use as age-diagnostic biomarkers, Geology, 35, 419-422, 2007.

Reissmann, J. H., Burchard, H., Feistel, R., Hagen, E., Lass, H. U., Mohrholz, V., Nausch, G., Umlauf, L., and Wieczorek, G.: Vertical mixing in the Baltic Sea and consequences for eutrophication - A review, Prog. Oceanogr., 82, 47-80, 2009.

Repeta, D. J., Ferron, S., Sosa, O. A., Johnson, C. G., Repeta, L. D., Acker, M., DeLong, E. F., and Karl, D. M.: Marine methane paradox explained by bacterial degradation of dissolved organic matter, Nature Geosci, 9, 884-887, 2016.

Schmale, O., Schneider von Deimling, J., Gülzow, W., Nausch, G., Waniek, J. J., and Rehder, G.: Distribution of methane in the water column of the Baltic Sea, Geophys. Res. Lett., 37, L12604, https://doi.org/10.1029/2010gl043115, 2010.

Schmale, O., Blumenberg, M., Kießlich, K., Jakobs, G., Berndmeyer, C., Labrenz, M., Thiel, V., and Rehder, G.: Aerobic methanotrophy within the pelagic redox-zone of the Gotland Deep (central Baltic Sea), Biogeosciences, 9, 4969-4977, https://doi.org/10.5194/bg-9-4969-2012, 2012.

Schmale, O., Krause, S., Holtermann, P., Power Guerra, N. C., and Umlauf, L.: Dense bottom gravity currents and their impact on pelagic methanotrophy at oxic/anoxic transition zones, Geophys. Res. Lett., 43, 5225-5232, 2016.

Schmale, O., Wäge, J., Mohrholz, V., Wasmund, N., Gräwe, U., Rehder, G., Labrenz, M., and Loick-Wilde, N.: The contribution of zooplankton to methane supersaturation in the oxygenated upper waters of the central Baltic Sea, Limnol. Oceanogr., 63, 412-430, 2018.

Schneider, B., Kaitala, S., Raateoja, M., and Sadkowiak, B.: A nitrogen fixation estimate for the Baltic Sea based on continuous $p \mathrm{CO}_{2}$ measurements on a cargo ship and total nitrogen data, Cont. Shelf Res., 29, 1535-1540, 2009.

Schneider, B., Gülzow, W., Sadkowiak, B., and Rehder, G.: Detecting sinks and sources of $\mathrm{CO}_{2}$ and $\mathrm{CH}_{4}$ by ferrybox-based measurements in the Baltic Sea: Three case studies, J. Marine Syst., 140, 13-25, 2014

Scranton, M. I. and Brewer, P. G.: Occurence of methane in the nearsurface waters of the western subtropical North-Atlantic, DeepSea Res., 24, 127-138, 1977.

Sellner, K. G., Olson, M. M., and Kononen, K.: Copepod grazing in a summer cyanobacteria bloom in the Gulf of Finland, Hydrobiologia, 292, 249-254, 1994. 
Simon, M., Grossart, H. P., Schweitzer, B., and Ploug, H.: Microbial ecology of organic aggregates in aquatic ecosystems, Aquat. Microb. Ecol., 28, 175-211, 2002.

Sunda, W. G., Hardison, R., Kiene, R. P., Bucciarelli, E., and Harada, H.: The effect of nitrogen limitation on cellular DMSP and DMS release in marine phytoplankton: climate feedback implications, Aquat. Sci., 69, 341-351, 2007.

Tang, K. W., Dam, H. G., Visscher, P. T., and Fenn, T. D.: Dimethylsulfoniopropionate (DMSP) in marine copepods and its relation with diets and salinity, Mar. Ecol. Prog. Ser., 179, 71-79, 1999.

Tang, K. W., Visscher, P. T., and Dam, H. G.: DMSP-consuming bacteria associated with the calanoid copepod Acartia tonsa (Dana), J. Exp. Mar. Biol. Ecol., 256, 185-198, 2001.

Tang, K. W., Glud, R. N., Glud, A., Rysgaard, S., and Nielsen, T. G.: Copepod guts as biogeochemical hotspots in the sea: Evidence from microelectrode profiling of Calanus spp., Limnol. Oceanogr., 56, 666-672, 2011.

Tang, K. W., McGinnis, D. F., Frindte, K., Brüchert, V., and Grossart, H.-P.: Paradox reconsidered: Methane oversaturation in well-oxygenated lake waters, Limnol. Oceanogr., 59, 275-284, 2014.

Teikari, J. E., Fewer, D. P., Shrestha, R., Hou, S., Leikoski, N., Mäkelä, M., Simojoki, A., Hess, W. R., and Sivonen, K.: Strains of the toxic and bloom-forming Nodularia spumigena (cyanobacteria) can degrade methylphosphonate and release methane, ISME J., 12, 1619-1630, 2018.

Thiel, V. and Hoppert, M.: Fatty acids and other biomarkers in two Early Jurassic concretions and their immediate host rocks (Lias $\delta$, Buttenheim clay pit, Bavaria, Germany), Org. Geochem., 120, 42-55, 2018.

Thor, P., Dam, H. G., and Rogers, D. R.: Fate of organic carbon released from decomposing copepod fecal pellets in relation to bacterial production and ectoenzymatic activity, Aquat. Microb. Ecol., 33, 279-288, 2003.

Tong, M., Zhou, Q., Kulis, M. D., Jiang, T., Qi, Y., and Anderson, M. D.: Culture techniques and growth characteristics of Dinophysis acuminata and its prey, Chin. J. Oceanol. Limn., 28, 12301239, 2010.

Tuboly, E., Szabó, A., Garab, D., Bartha, G., Janovszky, Á., Eros, G., Szabó, A., Mohácsi, Á., Szabó, G., Kaszaki, J., Ghyczy, M., and Boros, M.: Methane biogenesis during sodium azide-induced chemical hypoxia in rats, Am. J. Physiol.-Cell Ph., 304, C207C214, 2013
Utermöhl, H.: Zur Vervollkommnung der quantitativen Phytoplankton-Methodik, Mitteilungen der Internationalen Vereinigung für Limnologie, 9, 1-38, 1958.

Vahtera, E., Laanemets, J., Pavelson, J., Huttunen, M., and Kononen, K.: Effect of upwelling on the pelagic environment and bloom-forming cyanobacteria in the western Gulf of Finland, Baltic Sea, J. Marine Syst., 58, 67-82, 2005.

Wang, Q., Dore, J. E., and McDermott, T. R.: Methylphosphonate metabolism by Pseudomonas sp. populations contributes to the methane oversaturation paradox in an oxic freshwater lake, Environ. Microbiol., 19, 2366-2378, 2017.

Wasmund, N.: Occurrence of cyanobacterial blooms in the baltic sea in relation to environmental conditions, Int. Rev. ges. Hydrobio., 82, 169-184, 1997.

Wasmund, N., Nausch, G., and Voss, M.: Upwelling events may cause cyanobacteria blooms in the Baltic Sea, J. Marine Syst., 90, 67-76, 2012.

Welschmeyer, N. A. and Lorenzen, C. J.: Carbon-14 labeling of phytoplankton carbon and chlorophyll a carbon: Determination of specific growth rates, Limnol. Oceanogr., 29, 135-145, 1984.

Wiesenburg, D. A., Norman, J., and Guinasso, L.: Equilibrium solubilities of methane, carbon monoxide, and hydrogen in water and seawater, J. Chem. Eng. Data, 24, 356-360, 1979.

Wolfe, G. V., Steinke, M., and Kirst, G. O.: Grazing-activated chemical defence in a unicellular marine alga, Nature, 387, 894-897, 1997.

Yao, M., Henny, C., and Maresca, J. A.: Freshwater bacteria release methane as a byproduct of phosphorus acquisition, Appl. Environ. Microbiol., 82, 6994-7003, https://doi.org/10.1128/AEM.02399-16, 2016.

Zhang, Y. and Xie, H.: Photomineralization and photomethanification of dissolved organic matter in Saguenay River surface water, Biogeosciences, 12, 6823-6836, https://doi.org/10.5194/bg-126823-2015, 2015.

Zindler, C., Bracher, A., Marandino, C. A., Taylor, B., Torrecilla, E., Kock, A., and Bange, H. W.: Sulphur compounds, methane, and phytoplankton: interactions along a north-south transit in the western Pacific Ocean, Biogeosciences, 10, 3297-3311, https://doi.org/10.5194/bg-10-3297-2013, 2013. 